УДК 636.52/58.082 DOI 10.31210/visnyk2018.03.17

(C) 2018

\author{
Войтенко С. Л., доктор сільськогосподарських наук, \\ Васильєва О. О., кандидат сільськогосподарських наук
}

Полтавська державна аграрна академія

\title{
СУЧАСНИЙ ГЕНОФОНД КУРЕЙ УКРАЇНИ
}

\section{Рецензент - доктор сільськогосподарських наук А. А. Поліщук}

Подано аналіз стану галузі птахівництва (безпосередньою - курівництва) в племінних господарствах Украӥни. Визначено, щуо на початку 2018 року курей різного напряму продуктивності розводили в 14 племінних господарствах, але при цьому функціонувало лиме два племінних заводи $і 12$ племінних птахоплемрепродукторів другого порядку. Наявне поголів'я птиці відносилося до порід бірківська барвиста та білий плімутрок, а також кросів Кобб-500, Росс-308, Ломанн, Ломан Браун - Лайт, Ломан ЛСЛ - Класік $i$ Хай-Лайн W-36. Відсутність інформачії про полтавську глинясту та адлерську сріблясту породи в Державному реєстрі суб'єктів племінної справи у тваринництві за 2017 рік можна розцінювати як зникнення стад, а отже, $і$ порід в Украӥні. Надано коротку характеристику порід $і$ кросів курей, ̈̈х продуктивність, а також діяльність у якості суб'єктів племінної справи в птахівництві. Доведено, щуо селекційна робота проводиться лише з бірківською барвистою породою та білим плімутроком, а решта птичі - ие фінальний гібрид чи батьківські стада зарубіжних компаній. Встановлено повну залежність вітчизняного птахівництва від імпорту птиці, щзо ставить під загрозу безпеку краӥни.

Ключові слова: птахівництво, кури, породи, кроси, продуктивність, селекція.

Постановка проблеми. Одну з основних проблем людства - забезпечення продуктами харчування тваринного походження - не можна вирішити без птахівництва, особливо якщо врахувати, що цей вид виробляє не лише м'ясо, але і яйця. Яйця сільськогосподарської птиці (курей, індиків, качок, гусей, цесарок і перепілок) $є$ харчовим продуктом високої енергетичної і біологічної цінності завдяки вмісту в них повноцінних білків, жирів, багатьох вітамінів, значної кількості мінеральних солей і мікроелементів. М'ясо ж птиці хоча й дещо відрізняється від інших видів м'яса, але вважається дієтичним і рекомендується для харчування різних вікових груп населення, включаючи дітей.

Вважається, що через декілька років м'ясо птиці у загальному м'ясному балансі світу займатиме перше місце. Одночасно $з$ цим дефіцит м'яса у світі, включаючи й м'ясо птиці, не зменшиться, що зумовлюватиме інтенсивний розвиток птахівництва [12].
Приємно відмітити, що Україна входить в число провідних країн-експортерів м'яса птиці в різні країни світу, особливо Європу. Але така ситуація може змінитися 3 огляду на вимоги споживачів, яких уже не цікавить швидко вирощене м'ясо птиці й вони вимагають вирощувати бройлерів більш повільно й забивати їх не в $42-$ 45 днів, в 73-84 дні. Змінюються й вимоги до якості харчових яєць. Наразі при виробництві харчових яєць кури повинні утримуватися в «колоніальних» клітках, на багатоярусній підлозі 3 безвигульним та вільно вигульним утриманням, а не кліткових батареях традиційного типу, як це прийнято на більшості промислових комплексів України. Недотримання останніх вимог приведе до втрати ринків збуту цього виду продукції в Україні. Не додає оптимізму й той факт, що більша частина виробників яєць і м'яса від курей використовує імпортовану птицю.

Загальновизнаною $є$ думка про те, що технологія утримання птиці, рівень ії годівлі, виробництво якісної продукції $\epsilon$ досить важливими чинниками успішності галузі. Проте не менш важливою складовою даної галузі є порода птиці та наявність вітчизняної племінної бази. 3 урахуванням цього вважаємо за актуальне висвітлення дійсного стану племінного птахівництва України 3 характеристикою наявних порід і кросів курей.

Аналіз останніх досліджень і публікацій, у яких започатковано розв'язання проблеми. Птахівництво України наразі розвивається в спеціалізованих підприємствах, в господарствах населення, включаючи фермерів, а також суб'єктах племінної справи у птахівництві. Переважна більшість м'яса птиці і харчових яєць виробляється на птахівничих підприємствах, але певний внесок роблять і господарства населення.

Проте незалежно від потужності виробника, основним засобом виробництва продукції визнано породу. Птахівництво, яке характеризується значною різноманітністю видів, має свою унікальність, яка полягає не лише в диференціації порід і ліній за напрямом продуктивності, але й створенні кросів. 


\section{СІЛЬСЬКЕ ГОСПОДАРСТВО. ТВАРИННИЦТВО}

Такі методи досить інтенсивно застосовуються у курівництві, особливо при виробництві м'яса і харчових яєць, а також у качківництві.

Вітчизняне птахівництво, особливо курівництво, давно почало застосовувати кроси зарубіжного походження, які вважаються більш продуктивними, порівняно 3 вітчизняними породами. Вже в 2000 році серед наявного генофонду курей яєчного й м'ясного, а також комбінованого напрямів продуктивності в Україні було лише три породи: адлерська срібляста, полтавська глиняста і кучинська ювілейна. Решта курей відносилася до кросів за переваги поголів'я кросів «Білорусь-9» та «Ломан-Браун».

Позитивним аспектом для галузі на той час була робота по створенню курей вітчизняних кросів, таких як Борки-Колор, Борки-17, Борки2М, Прогрес та інші $[2,9]$.

Тенденція розвитку птахівництва за останні роки різко змінилася і наразі птахівництво, особливо курівництво, практично повністю залежить від імпорту племінних ресурсів. Доведено, що виробництво м'яса курей на промисловій основі повністю залежить від зарубіжного селекційного матеріалу, а виробництво яєць - на 84\% [11].

У науковій літературі дуже мало робіт, які б стосувалися розведення птиці, а також їх породного різноманіття. Коротка характеристика порід чи кросів наводиться в каталогах та підручниках, але ця інформація давно застаріла. Для галузі більш цікавою є інформація про стан ринків яєць i м'яса, годівлю i хвороби птиці, розвиток м'ясного птахівництва тощо [5, 6, 7]. Саме тому в основі наших досліджень - дійсний стан племінного птахівництва України 3 акцентом на біологічних особливостях сучасного генофонду птиці.

Мета досліджень - визначити породи і кроси курей, які $€$ основою сучасного виробництва продукції птахівництва в Україні.

Завдання досліджень - оцінити стан племінного курівництва України та надати коротку характеристику фактичної продуктивності птиці.

Матеріал і методи досліджень. Аналіз стану галузі птахівництва в суб' єктах племінної справи України проводили за використання інформативної бази даних - Державного реєстру суб'єктів племінної справи у тваринництві за 2017 рік [2]. Визначено кількість племінних стад та їх статус, продуктивність курей, а також наявність селекційних гнізд у лініях.

Коротка характеристика порід і кросів зроблена за результатами власних досліджень та використання ряду літературних джерел $[1,8,10]$.
Результати досліджень. Виробництво продукції тваринництва, включаючи птахівництво, неможливе без селекції, основним призначенням якої $є$ створення нових порід та удосконалення існуючих. Функціонування системи селекції у птахівництві узгоджується 3 наявністю племінних заводів, племінних птахорепродукторів, селекційних центрів та контрольно-випробувальної станції, діяльність і функції яких передбачені відповідними наказами Мінагрополітики та положеннями. Основними функціями племінного заводу в птахівництві є створення нових порід $\mathrm{i}$ кросів, а також проведення випробовування різних типів і ліній на поєднуваність для одержання кросів. Для племінного птахорепродуктора основним визнано виробництво племінної продукції для одержання батьківських форм гібридів або гібридної птиці певного кросу. У залежності від функцій птахорепродуктори розділяються на птахорепродуктор першого порядку, який працює 3 прабатьківськими формами кросу та окремими породами, які отримує 3 племзаводу або селекційного центру, здійснює схрещування прабатьківських форм за відповідними схемами, одержує батьківські форми і реалізує їх репродукторам II порядку, а також птахорепродуктор другого порядку, який працює з батьківськими формами кросу, які отримує 3 репродуктора I порядку, шляхом схрещування батьківських форм одержує племінну продукцію фінального гібриду (кросу), яку реалізує виробникам харчових яєць і м'яса птиці та населенню. Методичне керівництво племінною роботою у репродукторах здійснюють селекційні центри або племзаводи, із яких завезена птиця.

Проте вітчизняна система селекції у птахівництві дуже далека від прописаних положень, а точніше їі практично немає, оскільки в Україні відсутні племінні заводи і селекційні центри по більшості кросів курей, практично немає птахорепродукторів першого порядку, а племінні птахорепродуктори другого порядку працюють 3 птицею зарубіжних компаній без можливості створення власних генотипів.

На початку 2018 року генофонд птиці в суб'єктах племінної справи був представлений такими видами: кури, качки, гуси, індики, перепела і страуси.

Аналіз племінного птахівництва (безпосередньою - курей) дозволив визначити, що на початку 2018 року окремі породи і кроси були представлені лише одиничними стадами 3 мінімальною кількістю селекційних гнізд у лініях, в той час як інші мали розгалужену мережу племінних господарств та численне поголів'я птиці в них, 


\section{СІЛЬСЬКЕ ГОСПОДАРСТВО. ТВАРИННИЦТВО}

але не мали можливості займатися селекцією. Серед 14 дієвих суб'єктів племінної справи із розведення курей було лише два племінних завода, які розводили курей порід бірківська барвиста і білий плімутрок, та 12 племінних птахоплемрепродукторів другого порядку, в яких відсутні лінії та селекційні гнізда у них, тобто дана категорія господарств має лише батьківські стада або взагалі працює з гібридною птицею.

У племінних стадах України кури представлені породами і кросами яєчного, м'ясного та комбінованого яєчно-м'ясного і м'ясо-яєчного напрямів продуктивності. Вони відносяться до порід бірківська барвиста та білий плімутрок, а також кросів Кобб-500, Росс-308, Ломанн, Ломан Браун - Лайт, Ломан ЛСЛ - Класік і Хай-Лайн W-36. У 2017 році до Державного реєстру суб'єктів племінної справи у тваринництві не надійшло інформації про адлерську сріблясту породу курей, яку в попередні роки розводили в одному племінному птахорепродукторі Харківської області, а також полтавську глинясту породу, яку розводили теж в одному господарстві Полтавської області, що можна розцінювати як зникнення стад.

Перелік порід і кросів курей, їх поголів'я та продуктивність подано в таблиці 1.

Бірківську барвисту породу курей яєчного напряму продуктивності, яка була створена науковцями Інституту птахівництва УААН шляхом складного відтворного схрещування білого та кольорового леггорнів вітчизняної селекції, зараз розводять лише в одному племінному заводі Державної дослідної станції птахівництва НААН. Птиця добре почуває себе як при утриманні на підлозі, так і у клітках різного типу при вільному паруванні та штучному осіменінні. На час створення цієї породи несучість однієї несучки становила 255-265 яєць, вік досягнення 50\% інтенсивності яйцекладки - 160 днів, маса яєць у віці 52 тижні сягала 58-59 г, жива маса несушок становила 1,7-1,9 кг, а півнів - 2,4-2,8 кг; збереженість молодняка - 94-96 \%, вивід молодняку 88-92 \%. Наявність різних ліній у породі, а також їх схрещування 3 півнями батьківської лінії породи червоний род-айленд дозволяла отримувати колорсексних гібридних курчат із високою точністю їх сексування.

Середнє поголів'я курей цієї породи, яке утримується лише в одному племінному заводі Харківської області, на 01.01.2018 року налічувало 0,7 тис. голів за середньої несучості однієї несучки в рік 131 яйце. В стаді є селекційні гнізда в лініях, але їх небагато, що ускладнює селекцію з породою. Крім того, немає племінних птахорепродукторів, які б підпорядковувалися даному племінному заводу та працювали за єдиною селекційною програмою. Дану породу не реалізують на племінні цілі ні у вигляді яєць, ні племінного молодняку.

\section{1. Поголів'я та продуктивність курей в племінних стадах}

\begin{tabular}{|c|c|c|c|c|c|}
\hline \multirow[t]{2}{*}{ Порода / крос } & \multicolumn{2}{|c|}{$\begin{array}{c}\text { Кількість } \\
\text { суб'єктів племін- } \\
\text { ної справи } \\
\end{array}$} & \multirow{2}{*}{$\begin{array}{c}\text { Середнє поголів'я } \\
\text { дорослої птиці за } \\
\text { станом на } 01.01 .18, \\
\text { тис. голів }\end{array}$} & \multirow{2}{*}{$\begin{array}{l}\text { Середня несу- } \\
\text { чість однієї } \\
\text { несучки в рік, } \\
\text { шт. }\end{array}$} & \multirow{2}{*}{$\begin{array}{c}\text { Кількість } \\
\text { селекційних } \\
\text { гнізд у лінії, } \\
\text { шт. }\end{array}$} \\
\hline & $\Pi 3$ & ППР & & & \\
\hline \multicolumn{6}{|c|}{ Кури м’ясного напряму продуктивності } \\
\hline Крос "Кобб-500" & - & 6 & 2458,5 & 228 & - \\
\hline Крос "Pocc-308" & - & 2 & 316,9 & 146 & - \\
\hline \multicolumn{6}{|c|}{ Кури яєчного напряму продуктивності } \\
\hline Бірківська барвиста & 1 & - & 0,6 & 131 & 68 \\
\hline Крос "Ломанн" & - & 1 & 87,1 & 267 & - \\
\hline $\begin{array}{l}\text { Крос "Хай-Лайн" } \\
\text { W-36 }\end{array}$ & - & 1 & 57,7 & 242 & - \\
\hline Крос "Ломан-Браун" Лайт & - & 1 & 89,4 & 238 & - \\
\hline $\begin{array}{l}\text { Крос "Ломанн ЛСЛ - Кла- } \\
\text { сік" }\end{array}$ & - & 1 & 47,2 & 244 & - \\
\hline \multicolumn{6}{|c|}{ Кури м'ясо-яєчного напряму продуктивності } \\
\hline Білий плімутрок & 1 & - & 0,7 & 103 & 74 \\
\hline
\end{tabular}




\section{СІЛЬСЬКЕ ГОСПОДАРСТВО. ТВАРИННИЦТВО}

Білий плімутрок - порода, виведена більше 100 років тому в США шляхом схрещування порід кохінхін, брама, лангшан, чорна іспанська, яванска, полосата домініканська і леггорн. Спочатку птиця мала смугасте оперення, тому ii й назвали плімутрок. У кінці ХІХ століття плімутрок завезли в Європу, переважно Великобританію й Німеччину, де створили популяції з різним кольором оперення: білим, чорним, половим та іншим. Найбільшого використання зазнала популяцію плімутроків із білим оперенням, яка була невибагливою до умов утримання, мала міцну конституцію, поєднувала високу несучістю та ніжність м’яса. Несучість птиці становила 165-180 яєць, маса яєць - 55-60 г, вивід курчат 80-85 \%. Жива маса півнів - 3,2-3,7 кг, курей 2,7-3,0 кг. Дана порода $є$ невід'ємною складовою при створенні кросів м'ясного напряму продуктивності, де іiі використовують у якості материнської форми.

В Україні на початку 2018 року породу білий плімутрок м'ясо-яєчного напряму продуктивності розводили лише в одному племінному заводі Державної дослідної станції НААН в кількості 0,7 тисяч голів за середньої несучості однієї несучки за рік 103 яйця. В умовах племінного заводу виділені окремі лінії та селекційні гнізда в них, тобто проводиться племінна робота зі створення нових ліній [4], але немає відповідної структурної ієрархії, тобто підпорядкованих племінному заводу племінних птахорепродукторів, що ускладнює селекцію з породою.

Крос Росс-308 виведений у Великобританії компанією «Ross» за схрещування декількох порід курей м'ясного напряму продуктивності. Птиця цього кросу поєднує в собі високу м'ясну та яєчну продуктивність. Від курей батьківського стадо за 60 тижнів на початкову несучку одержують 164-169, вивід курчат становить 82,3$87,2 \%$, кількість добових курчат на початкову несучку - 123,9-141,6 голів. Молодняк під час вирощування в 42-денному віці досягає маси 2,5 кг, витрачаючи при цьому на 1 кг приросту живої маси 1,7 кг корму. Забійний вихід туші на рівні $71-75 \%$.

В Україні птиця розводиться в трьох племінних птахорепродукторах другого порядку загальною чисельність 316,9 тисяч голів і характеризується невисокою середньою несучістю однієї несучки на рік (146 яєць). Безперечно, в цих суб'єктах племінної справи немає прабатьківських ліній та селекційних гнізд у лініях, а лише батьківські, щоправда, теж без селекційних гнізд, що не заважає реалізації на племінні цілі яєць та добового молодняка в значних об'ємах, відповідно, 25116,3 тис. штук яєць та 9042,2 тис. голів добового молодняка.

Кури кросу Кобб-500 належать до птиці м'ясного напряму продуктивності, який створила американська компанія «Cobb». Птиця даного кросу вибаглива до умов утримання і годівлі й має низьку яйценосність, але високу інтенсивність росту. У 24-тижневому віці курочки мають живу масу 2,8 кг, а півники - 3,4 кг. Вік досягнення 50\% яйцекладки складає 23-24 тижні, несучість на початкову несучку - 159-175 яєць, вивід курчат - 84-85 \% за їх високої збереженості. Забійної маси 2,5 кг молодняк цього кросу досягає за 40-42 дні. Тушка характеризується великою грудкою та низьким вмістом жиру із забійним виходом туші більше $72 \%$.

На початку 2018 року птицю цього кросу в Україні розводили 6 племінних птахорепродукторів другого порядку Донецької, Запорізької, Київської, Харківської і Черкаської областей за загального поголів'я птиці 2458 тис. голів. Середня несучість однієї несучки в рік становить 228 яєць. Більшість племінних стад реалізують яйця на племінні цілі і лише одне племінне господарство реалізує племінний молодняк. При цьому в жодному із племінних стад немає селекційних гнізд.

Кури кросу Ломан створені німецькою компанією Lohmann Tierzucht GmbH шляхом схрещування вихідних порід, переважно род-айленд та білого плімутрока та їх гібридів у першому поколінні. Птиця аутосексна, шкаралупа яєць - коричнева. Вік досягнення 50 \% яйцекладки - 160 днів, а піку яйцекладки - 28-32 тижні. Кури цього кросу характеризуються високою несучістю. Маса яєць - 63-65 г.

На початку 2018 року птицю цього кросу в Україні розводили лише в умовах одного птахорепродуктора другого порядку в Полтавській області за загальної численності поголів'я птиці 87,1 тисяч голів. Середня несучість однієї несучки в рік становить 267 яєць. $92 \%$ одержаних яєць реалізуються на племінні цілі. В племінному стаді немає селекційних гнізд, оскільки утримується лише фінальний гібрид птиці.

Кури кросу Ломанн Браун-Лайт належать німецькій компанії «Lohmann Tierzucht» і аналогічні за походженням із кросом Ломанн Браун, але мають дещо меншу масу яйця та характеризується низькими витратами кормів на виробництво продукції.

На початку 2018 року птицю цього кросу в Україні розводили лише в одному племінному птахорепродукторі другого порядку в Київській області. 


\section{СІЛЬСЬКЕ ГОСПОДАРСТВО. ТВАРИННИЦТВО}

За загального поголів’ я курей 89,4 тисячі голів середня несучість однієї несучки в рік становила 238 яєць. За 2017 рік реалізовано 3321,7 тисяч добового молодняка.

Крос Ломанн ЛСЛ - Класік відноситься до яєчного напряму продуктивності i створений німецькою компанією «Lohmann Tierzucht» на основі поєднання птиці декількох ліній порід род-айленд та білий плімутрок, але його відмінністю від інших селекційних досягнень групи Ломанн є біла шкаралупа яєць. Несучість на початкову несучку фінального гібриду даної птиці у 80-тижневому віці становить 260-280 шт. при середній масі ясць 62-63 г.

В Україні наразі птицю цього кросу розводять лише в одному племінному птахорепродукторі другого порядку в Київській області. При загальному поголів “ї курей 47,2 тисячі голів середня несучість однієї несучки в рік становила 244 яєць. За рік господарство реалізувало 4308,5 тисяч добового молодняка.

Кури кросу Хай-Лайн W-36 відносяться до птиці яєчного напряму продуктивності, яка створена в США. Птиця цього кросу характеризується невеликими розмірами, легкою статурою, міцним здоров'ям та гарним імунітетом, високою яєчною продуктивністю та стресостійкістю. Збереженість птиці в середньому - 93$96 \%$. Несучість на початкову несучку у 80тижневому віці становить 240-300 яєць, але активна яйцекладка триває не довго - не більше 18 місяців. Від гібридних несучок кросу Хай - Лайн W-36 одержують яйця 3 білою шкаралупою середньою масою 63-65 г.

На початку 2018 року птиця кросу Хай-Лайн W-36 утримувалася лише в одному племінному птахорепродукторі другого порядку в Київській області, налічуючи 57,7 тисяч голів із середньою несучістю однієї несучки в рік 242 яйця. Яйця реалізують як харчові, не залишаючи нічого для виведення молодняка та реалізації в інкубатори.

Таким чином, оцінка генофонду курей України дозволяє зробити висновок про те, що на початку 2018 року в суб'єктах племінної справи в птахівництві розводили лише дві породи курей - бірківську барвисту та білий плімутрок, хоча в попередні роки в Державному реєстрі суб'єктів племінної справи у тваринництві була ще інформація про адлерську сріблясту породу та полтавську глинясту. Але наразі слід визнати їх зникнення, що свідчить не лише про втрату генофонду, але й звуження біорізноманітності пташиного світу.

Негативним моментом в курівництві є те, що в будь-якій породі чи кросі немає чітко визначеної підпорядкованості племінних стад, що вказує на неможливість селекційної роботи 3 ними. Навіть за наявності двох племінних заводів із розведення курей бірківської барвистої та білого плімутрока немає підпорядкованих їм племінних птахорепродукторів, а функції селекційного центру та контрольно-випробувальної станції виконує фактично одна й та ж установа. 3 точки зору продуктивності курей цих кросів, тобто середньої несучості однієї несучки в рік, відповідно, 131 яйце і 103 яйця, вони значно поступаються кросованій імпортованій птиці.

Серед різноманітності курей яєчного напряму продуктивності найбільш численними та продуктивними є кроси «Ломанн», «Ломанн ЛСЛ Класік» та «Хайл-Лайн» W36, в яких від однієї середньої несучки в рік одержано 242-267 яєць. Але діяльність племінних репродукторів із їх розведення повністю залежить від імпорту птиці, оскільки в стадах немає вихідних ліній та селекційних гнізд у них, а в Україні - племінних заводів і птахорепродукторів першого порядку, де б утримувалися прапрабатьківські та прабатьківські стада. Окремі племінні стада реалізують добовий молодняк фінальних гібридів, але більшість господарств реалізує лише харчові яйця.

До курей виключно м'ясного напряму продуктивності, які розводяться в племінних птахорепродукторах України, відносяться кроси «Кобб500» і «Росс-308». Племінні стада реалізують на племінні цілі як яйця, так і добовий молодняк цих кросів, хоча самі працюють лише із зарубіжними компаніями і не мають прабатьківських стад.

Висновок. У підсумку можна констатувати, що наявний генофонд курей в суб'єктах племінної справи птахівництва України - це кросована птиця зарубіжного походження, крім незначного поголів'я бірківської барвистої породи і білого плімутрока вітчизняної селекції, яка сьогодні надходить в Україну, а завтра - невідомо. Птиця в населення, яка давно кросована, не забезпечить попит у харчових яйцях, не говорячи про м'ясо.

М'ясо інших видів птиці - індиків, качок, гусей, страусів, перепела тощо - 3 огляду на наявність поголів'я цих видів та меншу інтенсивність росту, порівняно із бройлерами, теж не вирішить проблеми дешевого м'яса. До цього слід додати, що племінних стад із розведення птиці вищевказаних видів теж дуже мало, а щодо індиків, то взагалі відсутні, й вони теж використовують у виробництві в більшості імпортоване, кросоване поголів'я.

У зв'язку з цим слід визнати, що галузь птахівництва України давно залежить від зарубіжного виробника і цієї ситуації не змінити. 


\section{БІБЛІОГРАФІЯ}

1. Барановський Д. І. Генофонд свійських тварин України /Д. І. Барановський, В. І. Герасимов, В. М. Нагаєвич, А. М. Хохлов. - Харків: Еспада, 2005. - С. 129-132.

2. Белов Л. М. Результаты исследований по выявлению родительских форм нового кросса яичных кур / Белов Л. М., Терешко Г. Т. // Научно-технический бюллетень УНИИП. - Харьков, 1981. - № 10. - С. 7-8.

3. Державний реєстр суб'єктів племінної справи у тваринництві. - 2017. - Т.2 / База даних ІРГT НАAH України. http://animalbreedingcenter.org.ua/derjplemreestr (дата звернення: 10.02.2018)

4. Катеринич О. О. Заводська лінія Г2 породи Плимутрок Білий - вітчизняний представник птиці 3 комбінованою продуктивністю / О. О. Катеринич, С. М. Панькова, С. В. Руда // Матеріали XIII міжнар. конф. «Птахівництво 2017» (19-21 вересня 2017 року, Трускавець). - 2017. C. 61-66.

5. Катеринич О. А. Перспективы использования отечественного генофонда кур / Катеринич О. А., Панькова С. Н., Руда С. В. // Аграрний тиждень. - 2015. - №11 (302). - С. 70-71.

6. Кімак I. T. Аналіз ринку м'яса птиці та

\section{ANNOTATION}

Voitenko S. L., Vasylieva O. A. The modern gene pool of Ukrainian poultry.

The article analyzes the state of the poultry industry, directly - chickens, in breeding farms of Ukraine. It was determined that in the beginning of 2018, chickens of different productivity directions were bred in 14 breeding farms, but only two breeding plants and 12 breeding second-order breeding poultry workers were employed. The existing livestock of the bird referred to the breeds of Birkiv colored and white plimutrok, as well as crossbows Cobb-500, Ross-308, Lohmann, Lohman BrownLight, Lohmann LSL-Classic and High-Line W-36. The lack of information on Poltava clay and Adler silver rocks in the State Register of breeding subjects in livestock production in 2017 can be considered as the disappearance of herds, and consequently, of rocks in Ukraine.

The Birkiv colorful chicken breed of the egg production line, which was created by the scientists of the Institute of Poultry Farming of Ukrainian Academy of Agrarian Sciences through the complex reproductive crossbreeding of white and colored яєць в Україні / Збірник наукових праць ЧДТУ: Серія Економічні науки. - 2010. - Ч. І. - Вип. 25. - C. 71-73.

7. Мельник Б. Основні тенденції розвитку світового м'ясного птахівництва / Б. Мельник // Економіка України. - 2004. - № 1. - С. 32-35.

8. Пабат B. О. Каталог племінних ресурсів сільськогосподарської птиці України / В. О. Пабат, Д. М. Микитюк, В. В., С. О.Фролов та ін. К. : Атмосфера, 2006. - С. 30-31.

9. Подстрєшний О. П. Господарчо-корисні ознаки та генетична структура кросів яєчних курей / Подстрєшний О. П., Сахацький М. І., Паскевич Г. А. //Науковий вісник Львівської державної академії ветеринарної медицини ім. С. 3. Гжицького. - Львів, 2000. - Т. 2. - Ч. 3. - С. $120-124$.

10. Рубан Б. В. Птицы и птицеводство / Б. В. Рубан. - Харьков : Эспада, 2002. - С. 244-246.

11. Тваринництво України: стан, проблеми, шляхи розвитку (1991-2017-2030рр.) / За ред. М. І. Бащенка. - К.: Аграрна наука, 2017. - 160 с.

12. Фисинин В.И. Современная тенденция развития российского и мирового птицеводства / В. И. Фисинин // Ефективне птахівництво. 2006. - №11. - C. 8-12.

chickens of domestic breeding, is now breeding only in one breeding plant of State Research Station of Poultry Industry of National Academy of Agrarian Sciences. The average number of hens of this breed, which is kept only in one tribal plant of Kharkiv region, as of 01.01.2018 amounted to 0.7 thousand heads for the average carrying of one laying hen per year - 131 eggs.

In Ukraine, in early 2018, the white plimutrok breed of meat and egg production was breed only in one breeding plant of the State Research Station of National Academy of Agrarian Sciences in the amount of 0.7 thousand heads for the average carrying weight of one lozenge per year of 103 eggs.

In Ukraine, the Ross-308 Cross in three breeding poultry producers of the second order with a total of 316.9 thousand heads and it is characterized by a low average bearing of one laying hen per year 146 eggs.

In early 2018, chicken Cross Cobb-500 farmers of the second order of Donets' $k$, Zaporizhzhia, Kyiv, Kharkiv and Cherkasy regions bred the bird of this cross in Ukraine for a total number of birds - 
2458 thousand heads. The average carrying weight of one laying hen per year is 228 eggs.

In early 2018, the birds of Lohan Cross in Ukraine were bred only in the conditions of one second-rate poultry farm in Poltava region, with a total number of birds -87.1 thousand heads. The average carrying weight of one laying hen per year is 267 eggs.

Cross Lohmann LSL-Classic bird of this breed is breeding only in one breeding poultry farmer of the second order in Kyiv region. With a total livestock of chickens 47.2 thousand heads, the average bearing of one laying hen per year was 244 eggs.

At the beginning of 2018, the High-Line W-36 line was kept only in one pedigree poultry producer of the second order in Kyiv region, with 57.7 thousand heads with an average bearing of one laying hen per year -242 eggs.

A brief description of breeds and cross-breeds of chickens, their productivity, as well as activities as breeding subjects in poultry farming is provided. It has been proved that selection work is carried out only with the Birkiv colored rock and white plimutrok, and the rest of the birds are the final hybrid or parent herds of foreign companies. The complete dependence of domestic poultry production on imports of poultry has been established, which endangers the country's security.

Key words: poultry, chickens, breeds, crosses, productivity, breeding. 